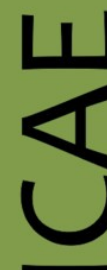

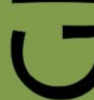

ex Instituto Archaeologico Universitatis de Rolando Eötvös nominatae

O

$\overrightarrow{0}$

山

$\leftarrow$

I

$\cup$

ه

$\leftarrow$

u

Ш

Z

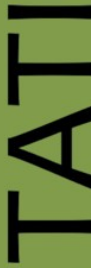

œ

ш

n

n

$\varnothing$
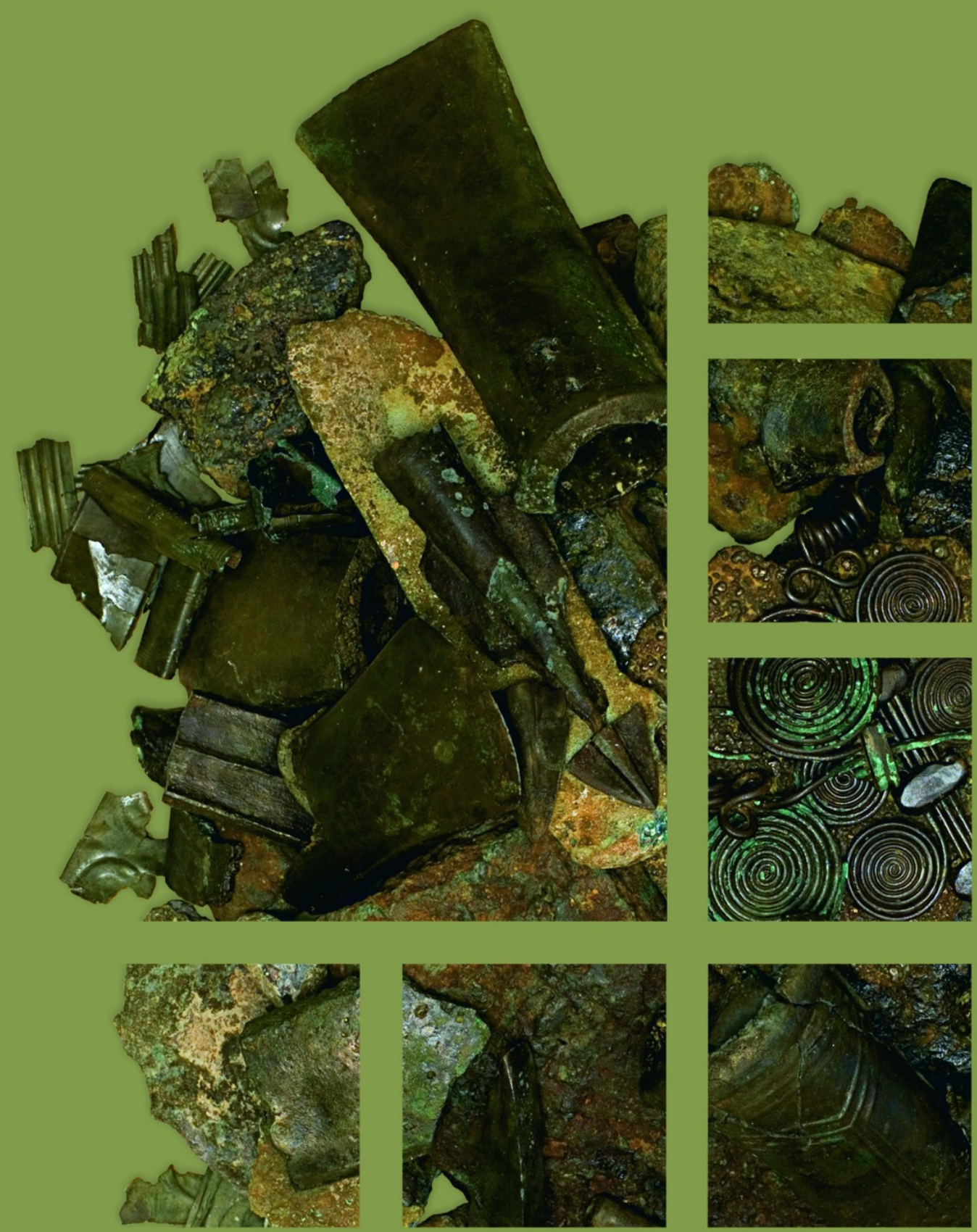


\section{Dissertationes Archaeologicae ex Instituto Archaeologico}

Universitatis de Rolando Eötvös nominatae Ser. 3. No. 2.

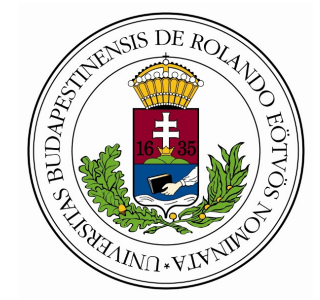

Budapest 2014 
Dissertationes Archaeologicae ex Instituto Archaeologico Universitatis de Rolando Eötvös nominatae

Ser. 3. No. 2.

Editor-in-chief:

DÁvid BARTus

Editorial board:

LÁsZló BARTOSIEWICZ

LÁSZLÓ BORHY

IsTVÁN FELD

GÁBOR KALLA

PÁL RACZKY

MiKLÓs SzABÓ

TIVADAR VIDA

Technical editors:

DÁvid BARTus

GÁBOR VÁCZI

ANDRÁs BÖDŐCS

DÁNIEL SZABÓ

Proofreading:

SZILVIA SzÖLLősI

Available online at http://dissarch.elte.hu Contact: dissarch@btk.elte.hu

$$
\begin{aligned}
& \text { PUBLIC } \\
& \text { KNOWLEDGE } \\
& \text { PROJECT }
\end{aligned}
$$

(c) Eötvös Loránd University, Institute of Archaeological Sciences

Budapest 2014 


\section{Contents}

\section{SElected PAPERS OF THE XI. Hungarian CONFERENCE on Classical Studies}

Ferenc BARNA

Venus mit Waffen. Die Darstellungen und die Rolle der Göttin in der Münzpropaganda

der Zeit der Soldatenkaiser (235-284 n. Chr.)

Dénes GABLER

A belsó vámok szerepe a rajnai és a dunai provinciák importált kerámiaspektrumában

Lajos MATHÉDESZ

Római bélyeges téglák a komáromi Duna Menti Múzeum gyújteményében

Katalin OtTOMÁNYI

Újabb római vicusok Aquincum territoriumán

Eszter SÜVEGH

Hellenistic grotesque terracotta figurines. Problems of iconographical interpretation

András SzABó

Some notes on the rings with sacred inscriptions from Pannonia

István VIDA

The coinage of Flavia Maxima Helena

\section{Articles}

Gábor TARBAY

Late Bronze Age depot from the foothills of the Pilis Mountains

Csilla SÁRó

Roman brooches from Paks-Gyapa - Rosti-puszta

András BöDőcs - Gábor KovÁcs - Krisztián ANDERKó

The impact of the roman agriculture on the territory of Savaria

Lajos JuHÁsz

Two new Roman bronzes with Suebian nodus from Brigetio

\section{FIELD REPORTS}

Zsolt MESTER - Norbert FARAGó - Attila KirÁLy

The first in situ Old Stone Age assemblage from the Rába Valley, Northwestern Hungary

Pál RACZky - Alexandra ANDERs - Norbert FARAgó - Gábor MÁRKus

Short report on the 2014 excavations at Polgár-Csőszhalom 
Preliminary Report on the first season of fieldwork in Berettyóúffalu-Szilhalom

Márton SzILÁgyi - András FüZESI - Attila VIRÁG - Mihály GASPARIK

A Palaeolithic mammoth bone deposit and a Late Copper Age Baden settlement and enclosure

Preliminary report on the rescue excavation at Szurdokpüspöki - Hosszú-dúlö II-III. (M21 site No. 6-7)

Kristóf FüLÖP - Gábor VÁcZI

Preliminary report on the excavation of a new Late Bronze Age cemetery

from fobbágyi (North Hungary)

Lőrinc TimÁr - Zoltán CzAJLik - András BöDőcs - Sándor PuszTA

Geophysical prospection on the Pâture du Couvent (Bibracte, France). The campaign of 2014

Dávid BARtus - László Borhy - Gabriella Delbó - Emese SzÁmadó

Short report on the excavations in the civil town of Brigetio (Szőny-Vásártér) in 2014

Dávid BARTus - László BorHy - Emese SzÁMADó

A new Roman bath in the canabae of Brigetio

Short report on the excavations at the site Szőny-Dunapart in 2014

Dávid BARTus - László Borhy - Zoltán CzAjlik - Balázs Holl -

Sándor PuszTA - László RuPNiK

Topographical research in the canabae of Brigetio in 2014

Zoltán CZAJLIK - Sándor BERECKI - László RUPNIK

Aerial Geoarchaeological Survey in the Valleys of the Mureș and Arieș Rivers (2009-2013)

Maxim MoRDovin

Short report on the excavations in 2014 of the Department of Hungarian Medieval

and Early Modern Archaeology (Eötvös Loránd University, Budapest)

Excavations at Castles Čabrad' and Drégely, and at the Pauline Friary at Sáska

\section{Thesis Abstracts}

Piroska Csengeri

Late groups of the Alföld Linear Pottery culture in north-eastern Hungary

New results of the research in Borsod-Abaúj-Zemplén County

Ádám Bíró

Weapons in the 10-11th century Carpathian Basin

Studies in weapon technology and methodology - rigid bow applications and southern import

swords in the archaeological material

Márta DARÓcZI-SzABó

Animal remains from the mid 12th-13th century (Árpád Period) village of Kána, Hungary

Károly BELÉNYESY

A 15th-16th century cannon foundry workshop in Buda

Craftsmen and technology of cannon moulding and the transformation of military technology

from the Renaissance to the Post Medieval Period 
István RINGER

Manorial and urban manufactories in the 17th century in Sárospatak

\section{BIBLIOGRAPHY}

László BORHY

565

Bibliography of the excavations in Brigetio (1992-2014) 


\title{
The impact of the roman agriculture on the territory of Savaria
}

\author{
ANDRÁs BöDőcs \\ Institute of Archaeological Sciences \\ Eötvös Loránd University \\ bodocs.andras@btk.elte.hu
}

GÁBOR KovÁcs

1. Dept. of Geophysics and Space Sciences Eötvös Loránd University

2. Geomega Ltd. skovacsgabor@caesar.elte.hu

\author{
KRISZTIÁN ANDERKó \\ Savaria Museum \\ Szombathely \\ anderko.krisztian@savariamuseum.hu
}

\begin{abstract}
The first reconstruction of the centuriatio of Savaria was attempted by András Mócsy, who tried to draw it with the utilization of mid-scale topographical maps. Since his publication there were no archaeological attempt in the last 40 years to prove his theory. In the last recent years we tried to continue the survey of the Savarian centuriatio's existence with support of GIS methods. Fortunately, an interesting relationship was noted between the informations of some archaeological excavations and the aerial archaeological phenomena, thus, we were able to build a predictive model-network of the assumed centuriatio. The new grid totally differs from the previous reconstruction. The predictive model's agglomeration of the assumed centuriatiotraces could be refined, and the refined model was controlled with the use of archaeological field survey and geophysical survey as well. The new reconstruction resulted new opportunities in the interpretation of excavated sites or former known roman roads and aqueducts, discovered in the last decades. An other interesting relationship could be found between the water courses that ran on the former territory of the colonia and the roman field boundary system: the probable impact of the roman agriculture on the landscape that affected the "premodern" (prior to the modern stream regulations) watercourse system.
\end{abstract}

\section{Centuriatio Savariensis}

Since András Mócsy has publicized the reconstruction attempt of centuriatio Savariensis in $1965^{1}$ and later in $1974^{2}$ only few articles have dealt ${ }^{3}$ with this important theme. Although Mócsy ${ }^{4}$ highlighted already in 1990 the importance of the archaeological research in this question, but this was not happened. The research of the first colony's centuriatio is an important step in the historic-economic reconstruction of the early roman Pannonia. The detailed topographical survey could solve the issue of the land use structure of the settlement's territory. The exact mapping of the field boundary system could help to reconstruct also the

\footnotetext{
1 Mócsy 1965.

2 Mócsy 1974.

3 Tóth 1977; NÉGYesi 2000.

4 Mócsy 1990.
} 


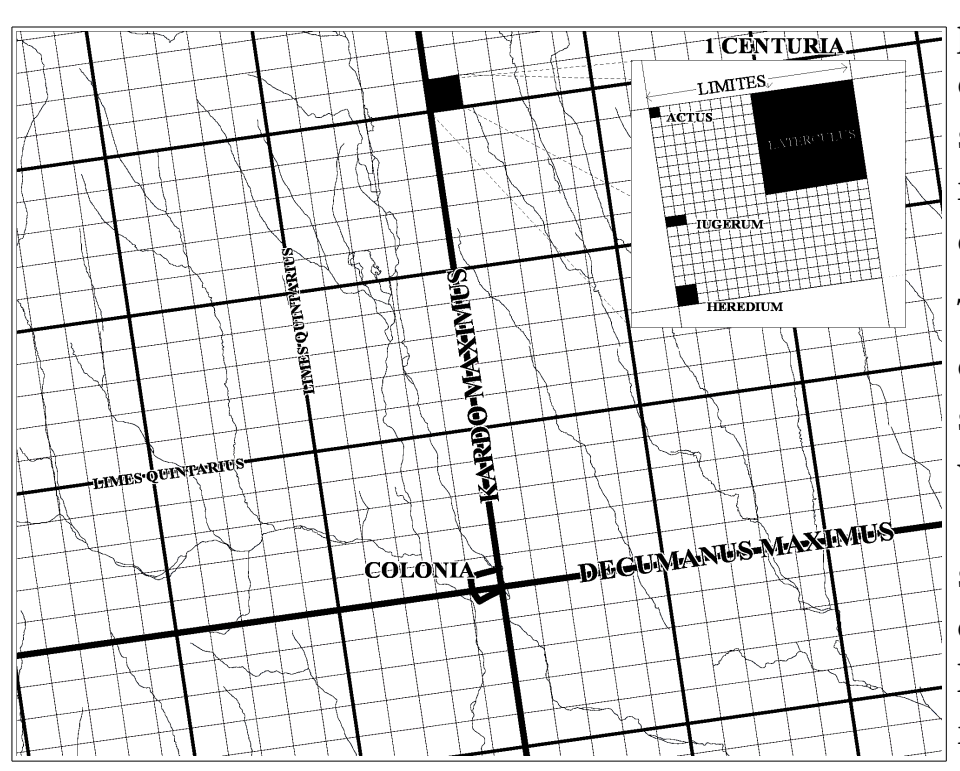

Fig.1. Centuriatio reconstruction around Savaria

property alteration of the first landowners and could strengthen or specify the process supposed in the research ${ }^{5}$ that has been set up based on the inscriptions of veterans.

The methods of the centuriatio's layout are well known from the written sources of ancient land surveyorwriters, commonly called as agrimensores: this is a practical land division process, divide the land in equal quadrats (centuriae). The same must have happened also in the surroundings of Savaria. The agrimensor Hyginus Gromaticus ${ }^{6}$ mentions the exaggerated adaptation of this methods in Pannonia: even the non-colonial landed properties were measured with the same action. Mócsy assumed a $16 \times 25$ actus (ca. $566 \times 885 \mathrm{~m}$ ) sized centuria unit in the orientation of $22-23^{\circ}$ geographical north to west. ${ }^{7}$ This was adapted also by Endre Tóth ${ }^{8}$ who extended Mócsy's grid to the whole assumed territory of Savaria: from the river Lafnitz (west) and river Ikva (north) to the river Rába (south and east). Unlike Northern Italia or Gallia, in Pannonia, although traffic roads of today (motorways and dirt roads) do show coherence with the suggested reconstruction, direct correspondence between ancient and today's road system should not have been supposed at the level of research of that time.

The latest results in the reconstruction have been based on archaeological excavations and aerial archaeological phenomena. The recently proposed "cell"-size (centuria) corresponds to the values mentioned in the text of the ancient land surveyors: a $20 \times 20$ actus sized rectangular centuria units, in the orientation of $10^{\circ}$ west to geographic north. ${ }^{9}$

In order to check the calculated values there were aerial archaeological reconnaissance, archaeological field survey and geophysical measurements planned with successful results on the theoretical borders and road crossings of this grid system.

The successful model, however, does not mean that the whole territorium of the colony could have been reconstructed, that kind of researches are still needed. The collection of the possible centuriatio's traces resulted in a remarkable observation: the recent watercourses (e.g. creeks) that run on the assumed territory of Savaria show in certain sections a good coherence with the model. The aim of our researches is to point out whether or not the roman agriculture affected the hydrological environment. Although it seems logical to suppose that roman land owners needed a solution for the irrigation of their field that might have been allocated far from a stream, we possess very few archaeological evidences for irrigation techniques of that kind in Pannonia.

5 Mócsy 1990; Harmatta 1972.

6 Const. Lim. 28.

7 Mócsy 1965; Mócsy 1974.

8 Tóтн 1977.

9 This value is ca. $8.3^{\circ}$ west to north in the Hungarian National Projection. 
The constant strife with the erosion, especially with the fluvial force appears already in the ancient land surveyor's texts. It was not simply a personal disadvantage when the landed property was wasted by a river, it had more legal consequences that had to be codificated in the ancient times. ${ }^{10}$ The fluvial devastation occurred also in other location where a fluvial sediment could enlarge an estate. The fact that detailed legal regulation was put in place shows the importance and diversity of land erosion issues. Some private stream regulation or bank strengthening were desired to avoid the disaster and in case of its omission the consequence for the landowner was detrimental.

On the other hand, the inviolability of the private properties against the interest of the community was demonstrated in case of M. Licinius Crassus, who refused the conduction of an aqueduct on his property. ${ }^{11}$ This might be, however, only the manifest of full power of a mighty man, but the situation of the aqueduct leading to Savaria near Bucsu shows that the conduction of the aqueduct possibly occurred mostly on public territory to avoid the confrontation with landowners. Here the aqueduct runs exactly on the reconstructed cardo line of the centuriatio in more than $2 \mathrm{~km}$ length. This phenomenon could mean that private property system influenced the design of the aqueduct-line, and it could date the aqueduct construction terminus post quem after the layout of the centuriatio.

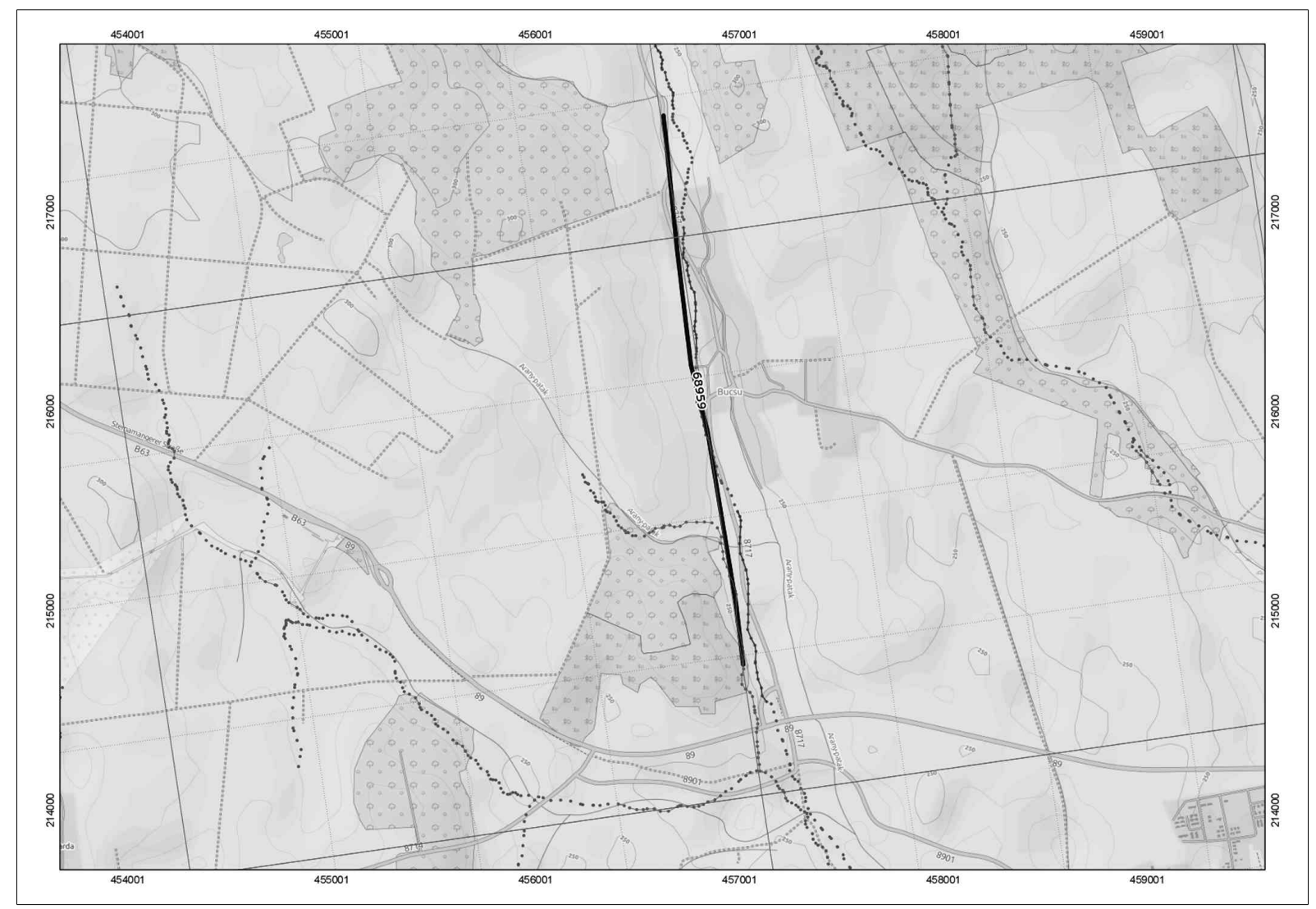

Fig.2. The traces of the roman aqueduct near Bucsu (Catalog ID of the Hungarian National Centre for cultural Heritage) and the reconstruction of centuriae and quintarii in that region. The dotted line shows the hydrological environment digitized from the maps of the II. Military Survey. 
Another ancient written source is informing us about the stream (or lake) regulation from the 3rd century AD in Pannonia. Aurelius Victor mentioned ${ }^{12}$ the so called emissio of the Lake Balaton (Pelso). The question, however, is still open about the methods and processes what this emissio might mean exactly. It underpins the stream regulation purpose of the roman central administration and it demonstrates that drainage of a creek should not be handled as isolated private action of landowners in Pannonia. That kind of landscape transfor mation might have had -similar to the fluvial erosion- also legal consequences.

The irrigation of the fields could have been configured also based on a rectangular system. In Mondragon (Vaucluse) the drainage system of the cadastre Orange "B" was organized according to the centuriatio: e.g the decumanus $S D$ (sinistra decumanum) VIII was the main water collector into which the water streamed from minor channels, like simple parcel terminals or from the bisector channel of the centuria. There were three types of channels identified by the depth and size. ${ }^{13}$

The afterlife of the channels belonging to the same cadastre mentioned above was reconstructed by Th. Odiot, D. Hote and P. Poupet ${ }^{14}$ in Gallia Narbonensis, in the region Drôme et Vaucluse. These channels were often renewed from the middle ages into the 18th century, time to time they were redirected from one to the parallel channel. Fundamentally that means the whole landscape character was determined by roman orthogonal directions of roads and channels, even if they suffered some transformation and the original pattern has disappeared in its entirety.

Based on these theories it was worth checking whether or not the recent hydrological status in county Vas could help in the reconstruction of the colony's territory.

The joint action, especially among the former brother-in-arms of the legio XV Apollinaris to manage the water regulation of the properties accordingly seems logical. The starting model conception - the centuriatio and the recent hydrological environment - to the survey is visible on the illustration below (Fig.3).

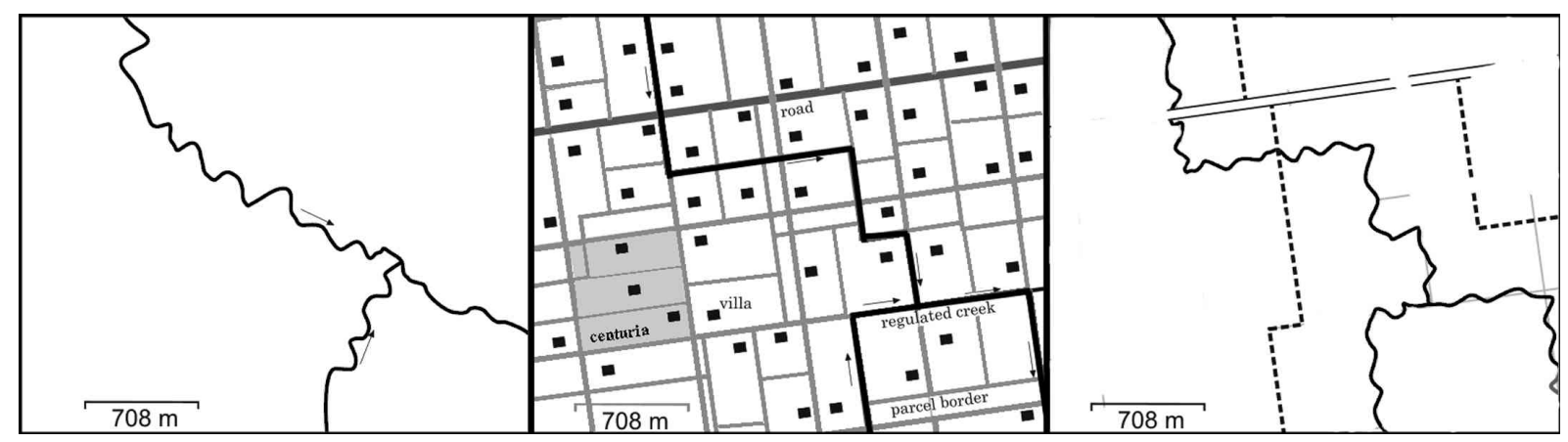

Fig.3. Theoretical phases of the stream (black line) network modifications. 1 - natural state of streams with their original flow direction; 2 - result of roman ditching, streams are regulated and flow parallel with the grid axes; 3 - after abandonment streams are approximately parallel with the grid axes but became wild, sinuous. Note the flow direction changes between 1-3 phases. 


\section{Basics of fluvial investigations}

Recent fluvial network of Western Pannonia has been significantly regulated from the 19th century, therefore recent stream network is not suitable for the investigation of their original shape. Section straightening, cuttings and draining were applied, thus recent shape of the streams significantly differs from their wild, premodern state of early 19 th century. ${ }^{15}$ Regulated streams cannot be used to detect correspondences between flow direction of stream sections and axes of modelled grid. However, map sheets of Second (also known as Franciscan) Military Survey of the Habsburg Empire ${ }^{16}$ proved to be a sufficient base for the investigations. ${ }^{17}$ Map sheets mostly depict the streams in their pre-regulated, wild state and their geodetic accuracy of the map sheets (150-200 m horizontal shift, retain shape ${ }^{18}$ ) are enough for such a studies. Detailed geographical investigation is needed to reconstruct the roman influences of hydrological system. Every stream has been digitized of the study area (3519.7 km) using Hungarian National Grid due to the local significance, high accuracy and meter based coordinates of the projection. The Fig. 3 shows the theory how the possible flow direction was transformed based on the parcel borders to support access to the landowners. In case of non-incised, alluvial streams, general tilting of the terrain (aspect) determines the natural flow direction. In order to survey whether the streams' are flowing into the direction of aspect or not, aspect mapping was applied.

General tilt of the study area is SW, however direction of several streams are similar to the already modeled centuriatio net. Assumingly the romans regulated the streams: ditches were dig in order to border their own properties and obtain non-split cultivatable area. Thus straight stream sections were created, parallel to the direction of centuria. After in the area the field system was abandoned, regulated streams initiated to erode and alter their trace freely again, ran wild (Fig. 3), similarly as were presented in Gallia.

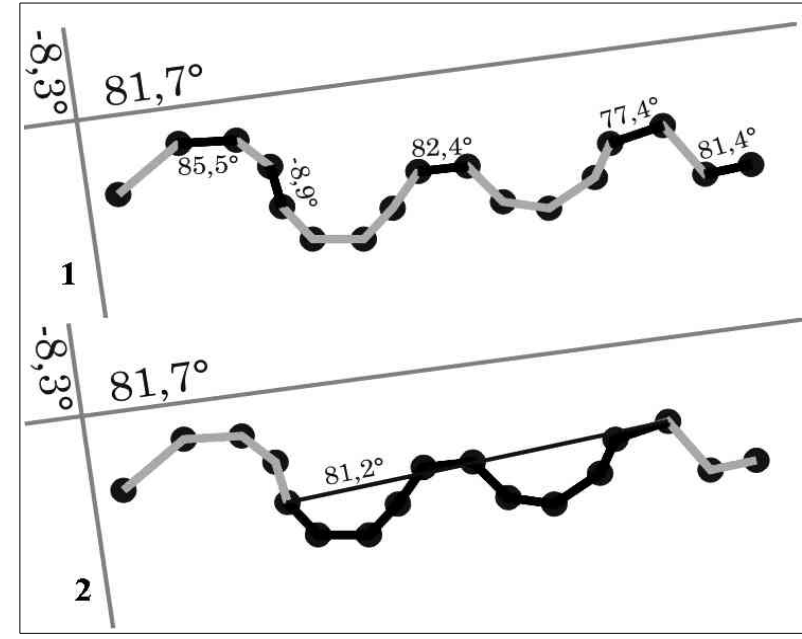

Fig.4. 1. Straight line directions.Black sections are almost parallel to the grid; 2 . The average direction of 10 breakpoint-section, the whole section is highlited if its average orientation parallel to the grid.

\section{Research methods}

Meandering, sinuous sections recently is not observable follow the net (Fig. 4), only the similar average flow direction is recognizable. These sections can be designated subjectively by an expert, but automatic method is needed. We aimed at the automatic selection of roman formed stream sections. After the designation of possible regulated sections, archaeological and/or geophysical surveys can be settled, thus further information can be gained about regulations, agriculture etc. Automatic designation of stream trace resulted from roman regulation is also useful to strengthen and/or modify the net parameters. 


\section{Stream section query/highlight}

Digitized rivers are handled as continuous straight line sections between the chains of breakpoints. Directions of the straight sections is easy to calculate using their endpoint coordinates, then sections can be presented according to their direction-similarity to the centuria axes (Fig. 4.1-2).

If the direction is close to the axial directions (within $5^{\circ}$ ) the section is presented with thick line, otherwise it remains invisible. That method is not sufficient to detect sections became wild running since the abandonment of them due to their curves formed since the roman age. Despite the average flow direction is similar to the sought, straight sections are varied between 0 and $360^{\circ}$ (Fig. 4.1).

Direction between non-neighbor breakpoints is similar to the above method, but the effect of curves are overwritten with the applied window size, which is a predefined distance between the applied breakpoints. If window size 10 is used, direction between 1st and 11th breakpoint is calculated, then 2 nd and 12th etc. (Fig. 4.2). The distance is not a constant value, due to the arbitrariness of the breakpoint distances. If a serial of straight sections within the window size is close to the axial directions (within $5^{\circ}$ ), the whole chain is presented with thick line (Fig. 4.2).

\section{Tectonic and morphologic pre-print?}

Surface of the study area is dissected by N-S and W-E morphological scarps (Fig. 5). Torony scarp W from Szombathely have proven to be the result of normal faults. ${ }^{19}$ The detailed geophysical and structural investigation ${ }^{20}$ explored WSW-ENE direction of main vertical faults, complemented with NW-SE secondary structural lines. These elements were not only detected along the morphological Torony scarp, but in the vicinity as well.

This case have high importance in our study because the faults possibly reach the surface can easily modify the direction of streams even their recent inactivity. The direction of the faults could not be accurately determine due to the sparse dataset, but possible effects of structural preformation on recent drainage network have to be noted.

Western part of the study area (W from Pinka River) consist of deeply incised N-S flowing parallel streams and parallel ridges. The direction of that features are parallel to the centuria axis, but due to the 30-50 $\mathrm{m}$ deep valleys, assumingly that are natural directions. However, eastern part is mostly flat, streams have only a few meters deep valley or channel. On that part, general tilt direction (aspect) differs from the streams flow direction with $\sim 50^{\circ}$. That could be the result of artificial regulating works. Close to the Sorok-Perint convergence, strongly meandering section can be seen. Geologically, tectonically that feature is unreasonable. ${ }^{21}$ Sections of the stream seems parallel to the centuria axes, although during the centuries became wild. The arguments suggest the section is a result of ditching at the borders of assets. 


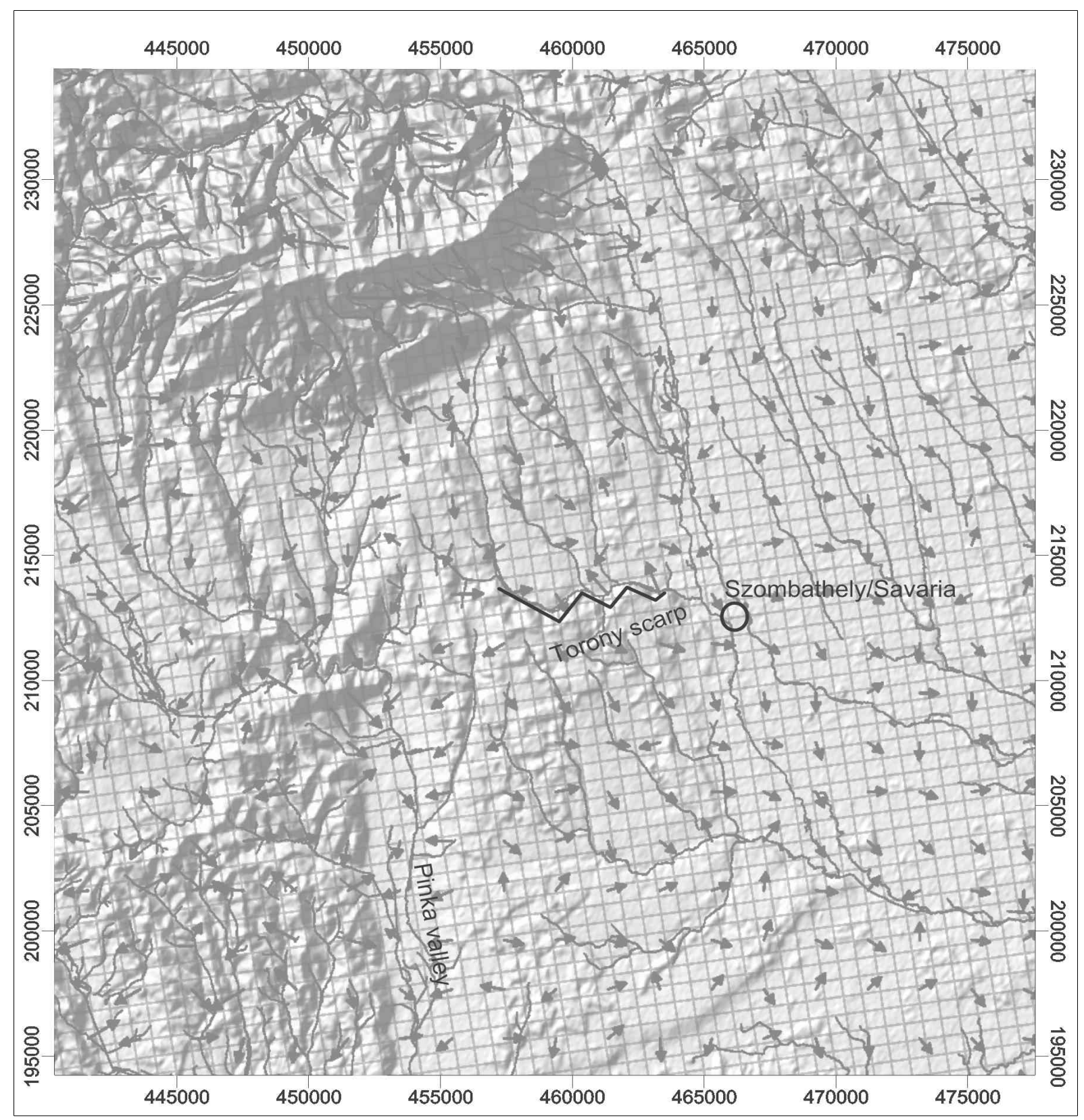

Fig. 5. Morphologic map of the study area with drainage network (thick grey line) and centuria grid (thin grey line). Arrows indicate the average aspect of $600 \times 600 \mathrm{~m}$, black lines are the assured fault segments by KovÁcs ET AL. Note that on several spots on the flat area around Szombathely, flow direction is parallel to the grid, instead of the general aspect.

\section{Ancient(?)- Perint section}

Archaeological excavations were carried out in subsequent stages on the plot bordered by the Kossuth Lajos Road and the Thököly István Road. According to the topography ${ }^{22}$ the area is situated south from the town center of Savaria surrounded by a wall, the fortification and its southwestern corner is located no more than 50 meters from it. According to the previous hypothesis, a semicircular medieval (or perhaps Roman period) rampart run south from the corners of this wall section which would have skimmed this area. ${ }^{23}$ The Roman road 
branching from the Amber Road, running around Savaria on the west and passing between the Perint Stream and the southwestern corner of the city wall was also expected to be identified here. $^{24}$

According to the previous expectations several Roman period features were unearthed during the excavations with a relatively uniform stratigraphic sequence. However, in the western part of the territory an unusual stratigraphic phenomenon could be observed. This northwest-southeast oriented feature was documented 30 meters long, and it divided the area into two distinct parts. East from the feature Roman period remains were found at the level of its appearance, while the fill was constituted by mixed stripes of debris containing also modern finds. After excavating the latter, a grey layer was found that seemed to be a deposition even at first sight. After cutting through the 100-120 cm thick deposition, it could be separated into several distinct parts. In its lower half a layer of reddish pebbles was situated, above that a layer containing a large amount of organic material, then a partly crossbedded layer of fine sand. Based on these it became clear that the remains of a stream were found here which - according to the testimony of the deposits - operated in a number of subequent phases with a varying intensity. The stripes rich in organic material indicate that in certain periods, when the level of flow was low, some kind of a lacustrine or swampy en vironment came into existence in the stream bed. The cross-bedded deposit suggests, how ever, a more intense, faster and more powerful flow (geological surveys were conducted by Zoltán Zentai geologist, University of West Hungary). The width of the stream bed could not be determined. A surface of about 9 meters could be excavated towards the west from its easter edge, but its other side was not found within this distance. According to my opinion this well-defined sometime stream bed could be related - already due to its position - to the Perint Stream today running about 80 meters west from it. The exact relationship between the two is still uncertain, a number of interpretations can be conceived. The excavated segment could possibly be the original stream bed, but this section of the Perint Stream could also run in a channel that was much broader than today. The most probable explanation is that an anabranch was found here diverging from the main bed. It is not clear whether this was a natural or a man-made branch, and it is also a question when it came into existence.

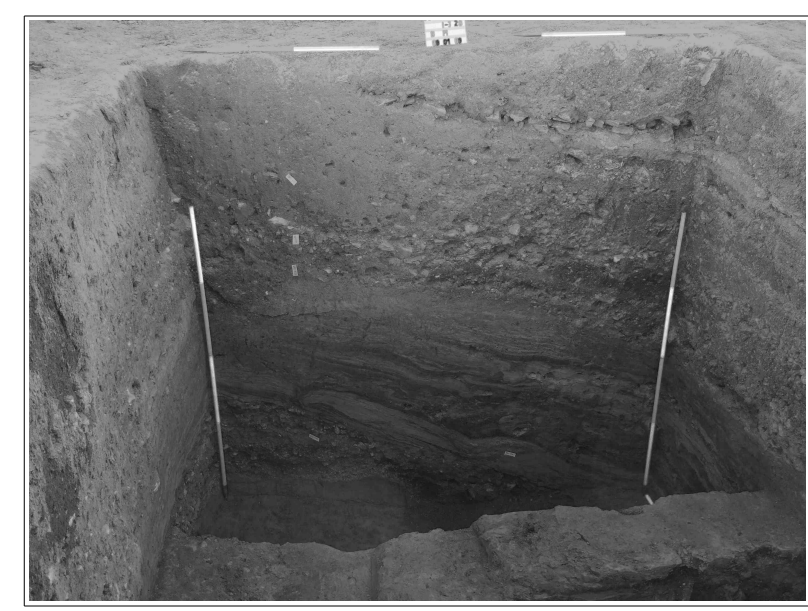

Fig.6. The layers of the excavated section (Photo: K. Anderkó).

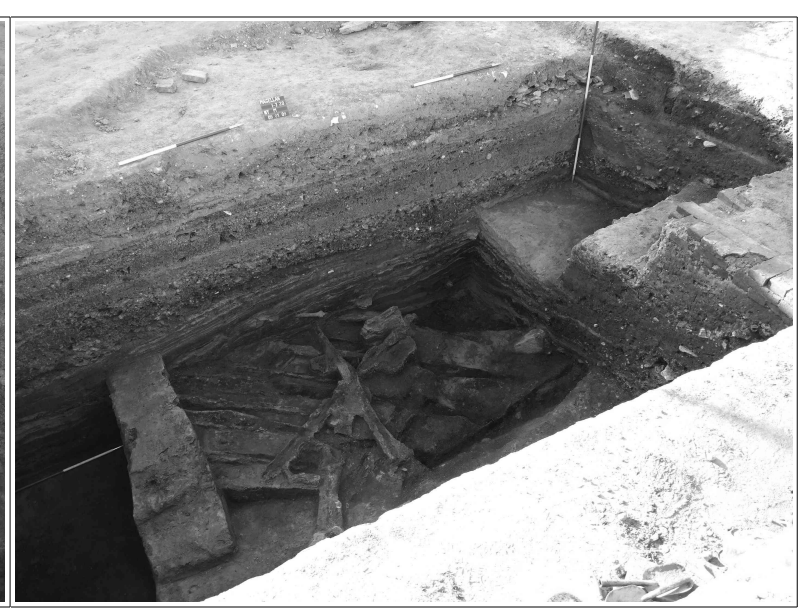

Fig. 7. The traces of the woodden palisade (Photo: K. Anderkó). 
At the same time, the unearthed segment can luckily be related to a similar phenomenon observed at the excavations in the Mátyás király Street. ${ }^{25}$ The line that can be determined by connecting the two sites follows that of the above mentioned rampart. ${ }^{26}$

The existence of this rampart and the connection between that and the stream bed is proved by a find uncovered at the excavation. In the deposition a row of postholes and the relatively well preserved remains of the related wooden structure were found: posts with a pointed end covered with wattle on one side. According to the dendrochronological analysis ${ }^{27}$ the posts were made of oak, the wattle of willow, and the wood used for the construction was cut around $1600 \mathrm{AD}$ This information luckily corresponds to the written sources according to which Szombathely was protected by a wooden palisade (provided with wattle) which was renovated, repaired several times (e.g. in 1491, 1592 and 1612). ${ }^{28}$ The line of this fortification can be identified on the early maps depictign the town, and also in the present structure of the settlement (along the Mátyás király Street, Légszeszgyár Street and Aréna Street). The excavated stream bed could be the ditch mentioned in the sources, and based on its direction it could probably join the Gyöngyös Stream.

Examining the broader environment of the excavated segment, the channel could possibly exist already in the Roman Period. It became clear during the archaeological research of the area located south from the town center of Savaria surrounded by a wall that the earliest settlement remains are located here. ${ }^{29}$ The stream branch cut exactly through this area. It is a question whether the hydrography or the settlement structure determined the arrangement. As the Roman roads running here are adjusted to the orientation of the stream bed, and the Gyöngyös Stream bordering the Roman town from the East is known to have been partly man-made, ${ }^{30}$ we consider the transformation of the natural environment as the more probable explanation. This stream branch must have been the result of a conscious transformation of the landscape (though of course a part of it could have been a natural feature), which contributed to the water management in the immediate environment of Savaria and the chanelling of the waste water collected from the town.

In summary, it is possible to say that a branch of the Perint Stream was found during the excavation which played an important role in the formation, structure and defense of SavariaSzombathely. Its line can still be distinguished in the $18^{\text {th }}$ century maps of the town. As, however, it was not very characteristically marked (as compared to the Perint and Gyöngyös Streams), it had probably become less significant by that time. As it had lost its function and the town needed more space, the stream bed was filled.

25 O. Sosztarits and J. Pásztókai-Szeőke, unpublished. Savaria Museum Documentation Department of Archaeology (SMRA) 1846-05 and SMRA 2195-07.

26 SoszTARits - MladoniczKi 2009, Fig.1.

27 The surveys were conducted by dr. András Grynaeus. SMRA 2502-09.

28 HoRváth 1993, 15-16.

29 MladoniczKi - Sosztarits 2009, 344-345.

30 KISS ET AL. 1998, 10-12. 


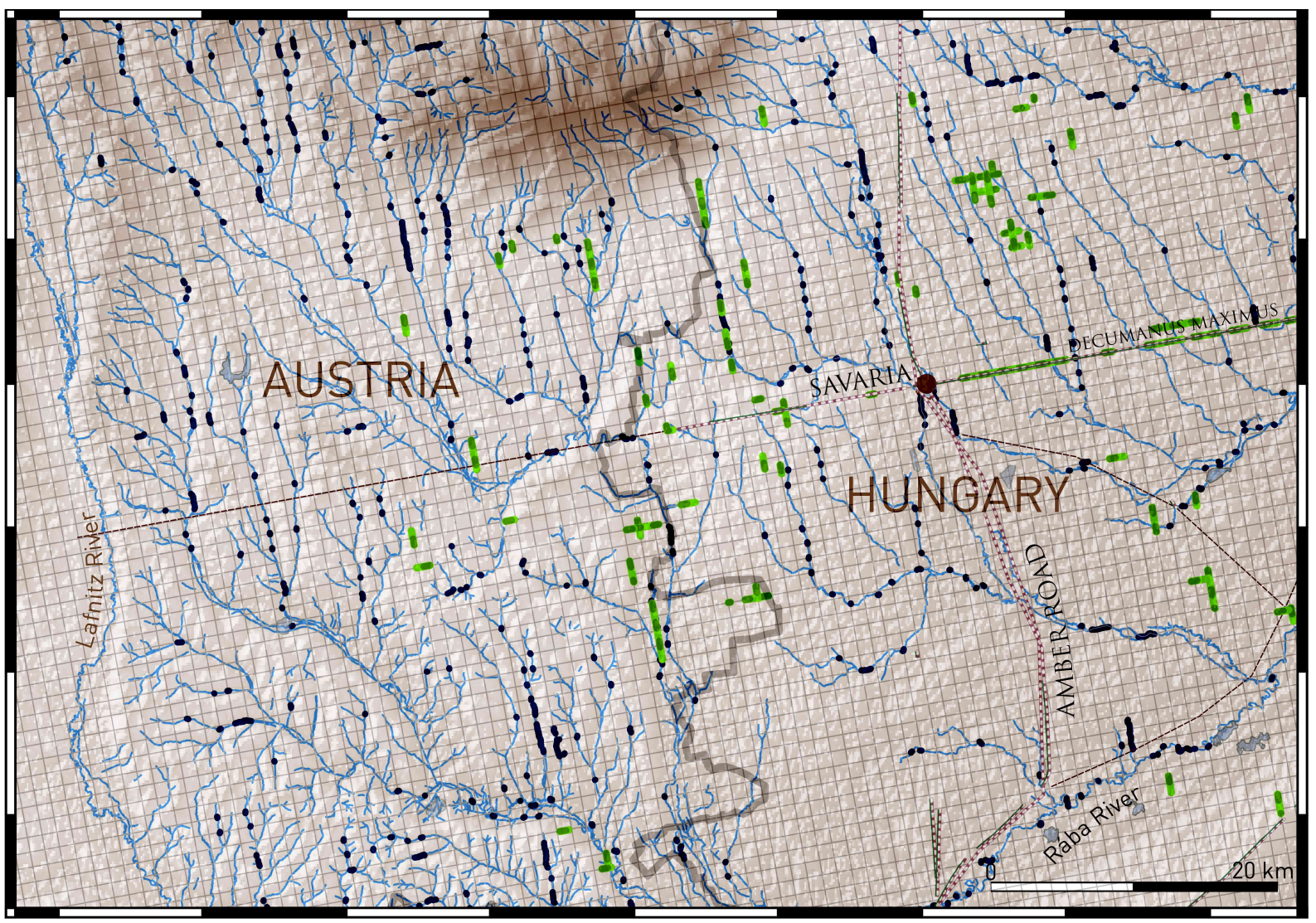

Fig.8. The traces of the querried streams (dark blue line) sections that fit exactly into the reconstructed centuriatio grid and the traces of soil and crop marks (green lines) visible on aerial photos.

\section{Conclusions}

Our study highlighted that hydrologic network had been modified during roman era around Savaria. Around the settlement, channelling could be done in order to secure city from floods and could strengthen the fortification as well. Around Savaria the natural stream beds of Perint - Arany-patak - Gyöngyös system and artificial channels are still not separable, therefore purposes of the works are still not clear. Other modifications are the ditching at the border of the properties. That was useful to create uniform assets, without streams crossing them. That kind of regulations were also useful to terminate swamp, drain wetlands and save assets from flooding. However, parallel and perpendicular stream network have to be interpret carefully. Morphological and tectonic situation can create similar shape of drainage network. In our case, the western part of the study area consists of deeply incised parallel valleys that direction are close to the N-S segment of the modelled centuria grid. Streams flowing in the valley bed of them are assumingly result of natural effects. Some kind of tectonic effects (en echelon fault system) and stream network take on their direction are also able to create quasi-perpendicular stream shape that could be also mistook with artificial stream network. In our case, direction of fault system segments and streams following that direction are differ from the centuria grid axes, therefore stream network can be separated from the artificial segments. 


\section{Acknowledgements}

The present research is partly realized in the frames of János Bolyai postdoctoral scholarship of MHAS (BO_115_12), TÁMOP 4.2.4.A/2-11-1-2012-0001 high priority "National Excellence Program - Elaborating and Operating an Inland Student and Researcher Personal Support System convergence program" project's scholarship support, using Hungarian state and European Union funds and co finances from the European Social Fund. Geological field observations and fluvial studies were supported by the grant of OTKA NK 83400. 


\section{References}

Berger, J-F. - Jung, C. 1996: Fonction, évolution et "taphonomie" des parcellaires en moyenne vallée du Rhône. Un exemple d'approche intégrée en archéomorphologie et en géoarqueologie. In: Chouquer, G. (ed.): Les formes du paysage II, Archéologie des parcellaires. Actes du colloque (Orléans, mars 1996), Paris, 95-112.

BöDőcs, A. - Kovács, G. 2011: A római kori birtokrendszer kialakítása és tájformáló hatása Pannoniában. Geodézia és kartográfia 63/3, 20-25.

Chouquer, G. - Favory, F. 1991: Les Paysage de l'Antiquité. Paris.

CzAJLIK, Z. - BöDőcs, A. - RupNik, L. 2012: Légi fényképezéses régészeti kutatások Magyarországon 2010-ben. Aerial photographic archaeological investigations in Hungary 2010. In: KISFALUdI, J. (ed.): Régészeti kutatások Magyarországon 2010. Budapest, 111-132.

Harmatta, J. 1972: A föld jogi helyzete Pannoniában. Antik Tanulmányok 52, 52-63.

Horváth, T. 1993: Szombathely a XV-XVIII. Században. Acta Savariensia 8. Szombathely.

Kiss, G. -Tóth, E. - ZÁgorhidi CzigÁny, B. 1998: Savaria - Szombathely története a város alapitásától 1526-ig. Szombathely.

KovÁcs, G. 2010: The advantages of using the Second Military Survey maps in fluvial studies. Acta Geodaetica et Geophysica Hungarica 45/1, 1-7.

Kovács, G. 2013: Linkage of young tectonics and surface development in the eastern alpine foothills (Fiatal tektonika és felszínfejlődés kapcsolata az Alpok keleti elöterében). Unpublished $\mathrm{PhD}$ thesis. Eötvös Loránd University. Budapest.

Kovács, G. - Fodor, L. - Kövér, Sz. - Molnár, G. - RAÁb, D. - Telbisz, T. - TimÁr, G. under review: Verification of structural control on landforms: a case study with complex methodology from low hilly area (western Pannonian Basin).

Mócsy, A. 1965: Savaria utcarendszerének rekonstrukciójához. Archaeologiai Értesító 92, 27-36.

Mócsy, A. 1974: Pannonia and Upper Moesia (The Provinces of the Roman Empire). London and Boston.

Mócsy, A. 1990: Földbirtok. In: Mócsy, A - Fitz, J. (ed.): Pannonia Régészeti Kézikönyve. Budapest, $125-127$.

Mladoniczki, R. - Sosztarits, O. 2003: Die Strecke der Bernsteinstraße in Savaria. In: Bíró, Sz. (ed.): Ex Officina... Studia in honorem Dénes Gabler. Győr, 325-356.

NÉGYeSI, L. 2000: A Borostyánkő-út kettős vonalvezetése és a Savaria környéki villahálózat. In: PEtercsák T. - VÁrAdi, A (ed): Heves Megyei Régészeti Közlemények 2., A Népvándorláskor Kutatóinak Kilencedik Konferenciája (Eger, 1998. szept. 18-20.). Eger, 79-84.

Pascual, P. C. 2013: Die Kontroverse De alluvione bei Gromatikern und Juristen . eTopoi. fournal for Ancient Studies 2, 1-23.

TAKÁcs, L. 2010: Az iszaplerakódás sorsa a római földmérés és jog tükrében. Debreceni fogi Múhely 7, 11-20.

Timár, G. - Molnár, G. - Székely, B. - Biszak, S. - Varga, J. - Jankó, A. 2006: Digitized maps of the Habsburg Empire - The map sheets of the second military survey and their georeferenced version. Arcanum, Budapest.

Tóth, E. 1977: Geschichte der Oberen Wart im 1. Jahrtausend. In: Triber, L. (ed.): Die Obere Wart. Festschrift zum Gedenken an die Wiedererrichtung der Oberen Wart im Fahre 1327. Innsburck, $77-100$. 